Relato de Caso / Case Report

\title{
Mediastinal nonleukemic granulocytic sarcoma with cardiac infiltration
}

\section{Sarcoma granulocítico mediastinal não associado à leucemia com infiltração cardíaca}

Gabrielle G. Lima

Francisco D. Rocha Filho

Francisco V.A. Ferreira

Bruno L. Linhares

Viviane C. Pereira

Helano C. Freitas
We report on a case of mediastinal granulocytic sarcoma with cardiac infiltration in a young man with no evidence of leukemia involving the bone marrow or peripheral blood. Diagnosis was accomplished by immuno-histochemistry with expressions of myeloperoxidase and CD99 antigens. The patient achieved clinical remission, but evolved with febrile neutropenia during chemotherapy and died. Although subclinical cardiac infiltrations are commonly found at autopsy in patients with acute non-lymphoblastic leukemia, only one case of involvement of the heart with granulocytic sarcoma in the absence of bone marrow disease has been published in the literature. A diagnosis of granulocytic sarcoma should not be excluded when the biopsy of the bone marrow does not show any evidence of leukemic infiltration. Rev. bras. hematol. hemoter. 2008; 30(4):339-341.

Key words: Granulocytic sarcoma; leukemia; cardiac infiltration.

\section{Introduction}

Granulocytic sarcoma (GS) is a rare extramedullary tumor composed of immature myeloid cells. It is usually associated with leukemia or other myeloproliferative disorders but can also occur without overt hematologic diseases. ${ }^{1,2} \mathrm{GS}$ can occur before, concomitantly, or after the overt development of acute or chronic myelogenous leukemia. ${ }^{3,4}$

Although this tumor is known to occur in almost every site of the body, cardiac involvement and a mediastinal mass are rare. ${ }^{3,5}$ When it does, the clinical picture may resemble lymphoma. ${ }^{6}$ The involvement of the heart with GS with no evidence of leukemia involving bone marrow or peripheral blood is very rare and usually diagnosed at autopsy. Only one report has been published in the literature. ${ }^{7,9}$ Histologic testing is essential to provide the proper diagnosis. ${ }^{10}$

We report the clinical and pathological features of a mediastinal GS with cardiac infiltration in a young adult man with no evidence of leukemia involving bone marrow or peripheral blood.

\section{Case Report}

A 31-year-old man with a five months history of dry cough and progressive dyspnea was admitted to our hospital due to pain in the left hemithorax when he was in dorsal decubitus. Physical examination showed vesicular murmur decreased in the right lung and irregular heart rhythm with a third heart sound. Patient had done previously echocardiography, which revealed mass of homogeneous texture of $58 \mathrm{~mm} \times 54 \mathrm{~mm}$, occupying approximately $65 \%$ of the left atrium, which is highly increased. The mass invades the cavity of the left ventricle (VE) in diastole through the mitral valve, which caused great restriction on the filling of the VE. He was submitted to surgery with diagnostic hypothesis of atrial myxoma. However, it was not held resection because the lesion was too extended. The diagnoses prior morphological and immunohistochemistry were angiossarcoma of low malignancy, paraganglioma heart and small cell carcinoma. Directed chemotherapy treatment was started with Etoposide and Cisplatin, with no good clinical

Instituto do Câncer do Ceará - Fortaleza-CE

Correspondence: Gabrielle Gurgel Lima

Instituto do Câncer do Ceará - Laboratório de Patologia

Rua Papi Júnior, 1222 - Bairro Rodolfo Teófilo

60430-230 - Fortaleza-CE - Brasil

Tel.: 558532884400 - Fax: 558532812865

E-mail:gabi_gurgel@yahoo.com.br 


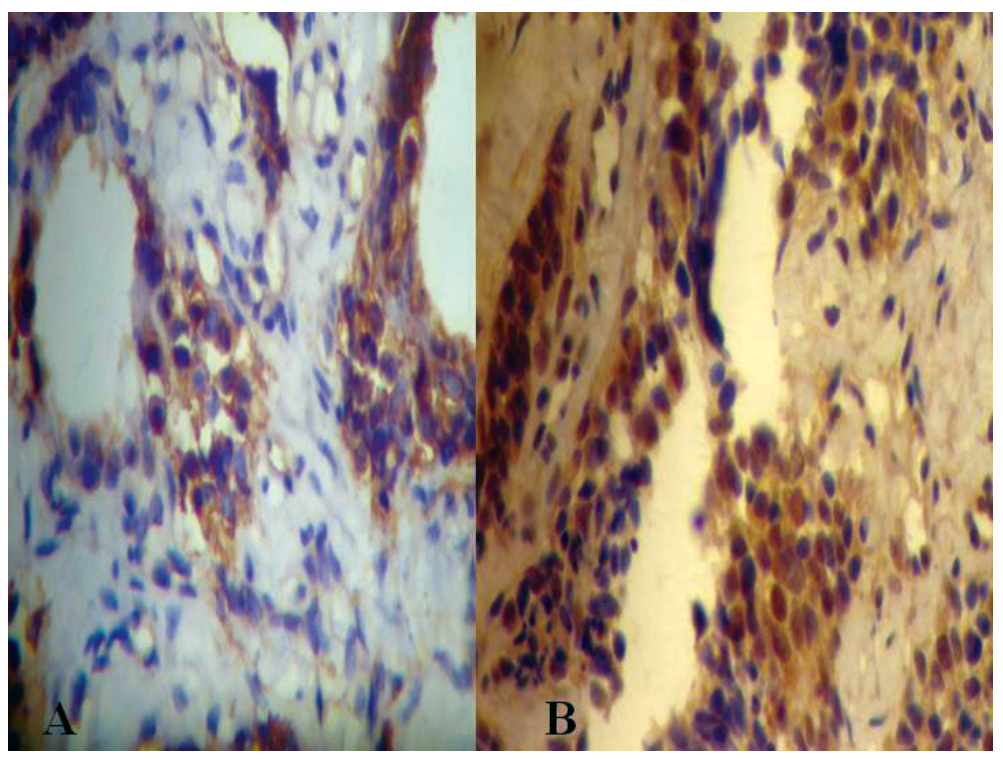

incidence of hematologic malignancies in mediastinal tumors. Early and accurate diagnosis of these tumors is essential because some of these patients require immediate treatment by hematology specialists. ${ }^{15}$

This case was originally misdiagnosed as angiossarcoma of low malignancy, paraganglioma heart and small cell carcinoma, which resulted in inappropriate therapy. The positivity for myeloperoxidase and MIC-2 (CD 99) at immunohistochemistry indicated the correct diagnostic of GS. Directed chemotherapy treatment was started with Daunorrubicina and Cytarabine, with clinical remission. Histopathologists should be aware that GS might occur in unusual extramedullary sites without evidence of bone marrow involvement. ${ }^{16}$

Immuno-histochemistry: A - Myeloperoxidase; B - MIC - 2 expression by neoplasic cells $(A B C \times 100)$.

response. Three months later, the thorax computed tomographic scan (CT) showed in the mediastinal mass expansive on upper and lower right paratraqueal location, pericardial spill with irregularity and discreet bulging on the wall of the left atrium. The examination of pleural fluid did not detect neoplastic cells. After two cycles of combination chemotherapy, the case was reviewed, which showed positivity for myeloperoxidase and MIC - 2 (CD99), diagnosing granulocytic sarcoma (Figure 1). Treatment was directed to GS with Daunorrubicina and Cytarabine, with clinical remission. Meanwhile, the patient presented febrile neutropenia during chemotherapy, evolving to death.

\section{Discussion}

Granulocytic sarcoma is usually associated with leukemia or other myeloproliferative disorders, but can also occur without overt hematologic disease, i.e. in patients with a normal bone marrow and no history of acute myelogenous leukemia. $^{11}$

Although cardiac infiltration is common in advanced stage of acute leukaemia, it is not usually diagnosed at life. ${ }^{12}$ But in this case the cardiac involvement was detected when the patient was still alive. The transthoracic echo revealed mass of homogeneous texture occupying the left atrium. Our research in literature disclosed the presence of only one case of mediastinal nonleukemic SG with cardiac infiltration. ${ }^{13}$

GS poses a diagnostic pitfall for both pathologists and oncologists. Previous literature showed that almost half of the patients with primary GS were misdiagnosed initially. ${ }^{14}$ Careful attention should be paid to the relatively high

\section{Resumo}

Relata-se o caso de um adulto jovem com sarcoma granulocítico (SG) mediastinal com infiltração cardíaca sem evidência de leucemia envolvendo medula óssea ou sangue periférico. O diagnóstico foi revelado pela imuno-histoquímica com positividade para mieloperoxidase e CD99. O paciente apresentou remissão clínica, porém evoluiu com neutropenia febril durante a quimioterapia e foi a óbito. Embora infiltrados cardiacos subclínicos sejam comumente detectados na autópsia em pacientes com leucemia aguda nãolinfoblástica, somente um caso de SG com envolvimento cardíaco na ausência de doença na medula óssea foi descrito na literatura. Um diagnóstico de $S G$ não deve ser excluída quando a biópsia da medula óssea não mostrar nenhuma evidência de infiltração leucêmica. Rev. bras. hematol. hemoter. 2008; 30(4):339-341.

Palavras-chave: Sarcoma granulocítico; leucemia; infiltração cardiaca.

\section{References}

1. D'Costa GF, Hastak MS, Patil YV. Granulocytic sarcoma of breast: an aleukemic presentation. Indian J Med Sci. 2007;61(3):152-5.

2. Ramasamy K, Lim Z, Pagliuca A, Devereux S, Ho AY, Mufti GJ. Acute myeloid leukaemia presenting with mediastinal myeloid sarcoma: report of three cases and review of literature. Leuk Lymphoma. 2007;48(2):290-4.

3. Jankovic M, Bonacina E, Masera G, Uderzo C, Galli MA, Ottaviani V, et al. Cardiac relapses in myeloid leukemia: case report and review of the literature. Pediatr Hematol Oncol. 1987;4(3):37-245.

4. Valbuena JR, Admirand JH, Gualco G, Medeiros LJ. Myeloid sarcoma involving the breast. Arch Pathol Lab Med. 2005;129(1):32-8.

5. Ouchiha M, Ferster A, Heiman P, Bujan W, Perlmutter N, Devalck C et al. Granulocytic sarcoma with mediastinal involvement. Arch Fr Pediatr. 1993;50(9):775-8. 
6. Toback A, Hasbrouck DJ, Blaustein J, Ershler WB. Granulocytic sarcoma of the anterior mediastinum. Am J Med Sci. 1985; 290 (5):206-8.

7. Kara IO, Sahin B, Paydas S, Kara B. Granulocytic sarcoma of the heart: extramedullary relapse of acute myeloblastic leukemia after allogeneic stem cell transplantation successfully treated by chemotherapy alone. Leuk Lymphoma. 2005;46(7):1081-4.

8. Marcos-Alberca P, Ibáñez B, Rey M, Román A, Rábago R, Orejas $\mathrm{M}$ et al. Cardiac granulocytic sarcoma (chloroma): in vivo diagnosis with transesophageal echocardiography. J Am Soc Echocardiogr. 2004;17(9):1000-2.

9. Makaryus AN, Tung F, Liu W, Mangion J, Kort S. Extensive neoplastic cardiac infiltration in a patient with acute myelogenous leukemia: role of echocardiography. Echocardiography. 2003; 20(6):539-44.

10. Shea B, Reddy V, Abbitt P, Benda R, Douglas V, Wingard J. Granulocytic sarcoma (chloroma) of the breast: a diagnostic dilemma and review of the literature. Breast J. 2004;10(1):48-53.

11. Breccia M, Petti MC, Fraternali-Orcioni G, Monarca B, Latagliata R, DElia GM et al. Granulocytic sarcoma with breast and skin presentation: a report of a case successfully treated by local radiation and systemic chemotherapy. Acta Haematol. 2000;104 (1):34-7.

12. Orts M, Ribera JM, Calatrava A, Larrouse E, Catalán R, Navarro JT et al. Pseudotumorous cardiac infiltration in a patient with acute monoblastic leukemia. Med Clin (Barc). 1996;106(14):545-7.

13. Foucar K, Foucar E, Willman C, Horvath A, Gerety RL. Nonleukemic granulocytic sarcoma of the heart: a report of a fatal case. Am J Hematol. 1987;25(3):325-32.

14. Wong WS, Loong F, Ooi GC, Tse TC, Chim CS. Primary granulocytic sarcoma of the mediastinum. Leuk Lymphoma. 2004;45(9):1931-3.

15. Satouchi M, Urata Y, Ueda S, Kotani Y, Kado T, Adachi S et al. Clinical evaluation of mediastinal hematologic malignancies (lymphoma and granulocytic sarcoma). Nihon Kokyuki Gakkai Zasshi. 2003;41(8):507-13.

16. McCluggage WG, Boyd HK, Jones FG, Mayne EE, Bharucha H. Mediastinal granulocytic sarcoma: a report of two cases. Arch Pathol Lab Med. 1998;122(6):545-7.

Avaliação: Editor e dois revisores externos

Conflito de interesse: não declarado

Recebido: 14/02/2008

Aceito $16 / 04 / 2008$ 